\title{
Overexpression of wild-type p21Ras plays a prominent role in colorectal cancer
}

\author{
SHUANG BAI ${ }^{1}$, QIANG FENG ${ }^{2}$, XIN-YAN PAN ${ }^{2}$, HONG ZOU $^{2}$, HAO-BIN CHEN $^{2}$, PENG WANG $^{1}$, \\ XIN-LIANG ZHOU ${ }^{1}$, YAN-LING $\mathrm{HONG}^{3}$, SHU-LING SONG ${ }^{2}$ and JU-LUN YANG ${ }^{1-3}$ \\ ${ }^{1}$ Faculty of Medicine, Kunming University of Science and Technology, Kunming, Yunnan 650500; \\ ${ }^{2}$ Department of Pathology, Kunming General Hospital, Kunming, Yunnan 650032; \\ ${ }^{3}$ Department of Pathology, Kunming Medical University, Kunming, Yunnan 650031, P.R. China
}

Received August 25, 2016; Accepted February 16, 2017

DOI: $10.3892 /$ ijmm.2017.2903

\begin{abstract}
Colorectal cancer (CRC) is the most common gastrointestinal type of cancer. The overexpression of Ras proteins, particularly p21Ras, are involved in the development of CRC. However, the subtypes of the p21Ras proteins that are overexpressed and the mutation status remain unknown restricting the development of therapeutic antibodies targeting p21Ras proteins. The present study aimed to investigate the mutation status of ras genes associated with Ras proteins that are overexpressed in CRC and explore whether or not wild-type p21Ras could be a target for CRC therapy. p21Ras expression was examined immunohistochemically in normal colorectal epithelium, benign lesions and malignant colorectal tumor tissues by monoclonal antibody (Mab) KGH-R1 which is able to react with three types of $\mathrm{p} 21 \mathrm{Ras}$ proteins: H-p21Ras, N-p21Ras and K-p21Ras. Then, the expression levels of p21Ras subtypes were determined in CRC by a specific Mab for each p21Ras subtype. Mutation status of ras genes in p21Ras-overexpressing CRC was detected by DNA sequencing. There was rare p21Ras expression in normal colorectal epithelium but a high level of p21Ras expression in CRC, with a significant increase from normal colorectal epithelium to inflammatory polyps, low-grade intraepithelial neoplasia, high-grade intraepithelial neoplasia and invasive colorectal adenocarcinoma, respectively. Overexpression of $\mathrm{K}$-p21Ras was found in all CRC tissues tested, overexpression of N-p21Ras was found in $85.7 \%$ of the CRC tissues, while H-p21Ras expression was not found in any CRC tissue. DNA sequencing showed that there were no $\mathrm{K}$-ras mutations in $60 \%$ of the K-p21Ras-overexpressing CRC, while $40 \%$ of the CRC tissues harbored $\mathrm{K}$-ras mutations. $\mathrm{N}$-ras mutations were not found in any N-p21Ras-overexpressing CRC. Our findings
\end{abstract}

Correspondence to: Dr Ju-Lun Yang, Department of Pathology, Kunming General Hospital, 212 Daguan Road, Kunming, Yunnan 650032, P.R. China

E-mail: yangjulun@sina.com

Key words: colorectal cancer, p21Ras, overexpression, mutation, wild-type indicate that overexpression of wild-type p21Ras may play a prominent role in the development of CRC in addition to ras mutations and could be a promising target for CRC therapy.

\section{Introduction}

Colorectal cancer (CRC) is the most common gastrointestinal malignancy, and is one of the leading causes of cancer-related deaths worldwide. Approximately 50,000 individuals die of CRC each year. The estimated number of deaths are 26,020 and 23,170 for men and women, respectively, in 2016 (1).

Surgery, chemotherapy and irradiation remain the most common treatments of this devastating disease. Yet, the therapeutic effect of these traditional treatments is not as effective as expected (2). Therefore, improvement in the therapeutic approach is imperative for more efficacious treatment of CRC. Targeted therapy is a new treatment for human cancers and is a developing future trend. Several targeted drugs have been used clinically for CRC therapy, such as cetuximab (3) and panitumumab (4), monoclonal antibodies which target the epidermal growth factor receptor (EGFR). EGFR is overexpressed in $60-70 \%$ of CRC cases, and these patients could benefit from EGFR-targeted therapy $(5,6)$. Unfortunately, cetuximab is ineffective for patients without EGFR overexpression or with EGFR extracellular domain mutations. Thus, it is necessary to identify new targets of therapy in EGFR signaling pathways.

The Ras gene, which locates at the downstream of EGFR in the RAS/RAF/MAPK pathway plays a major role in the development of CRC (7). $K$-ras mutation is an early event in colorectal tumorgenesis (8-10), and ocurs in 30-60\% of all CRC cases (11-18). However, $N$-ras mutations are rare in CRC (19). Glarakis et al found that the incidence of $N$-ras mutations is $1.3 \%$ in CRC (1/76) (20). H-ras mutations are far less common. From COSMIC database, among 765 colon adenocarcinomas only $1 \%$ were found to harbor $\mathrm{H}$-ras mutation (21). Mutant p21Ras resulting from mutations of the ras gene abolish GAP-induced GTP hydrolysis of Ras proteins, leading to constitutive activation of ras (GTP-bound active form). Such activating mutations result in constitutive signaling, and thereby cause an increase in proliferation and in malignant transformation (22). 
As known, most oncogenes play a carcinogenic role by gene amplification and the overexpression of wild-type proteins $(23,24)$. Ras proteins, p21Ras, are overexpressed in $29-76 \%$ of CRC (25), but the subtype of p21Ras proteins that are overexpressed in $\mathrm{CRC}$ and mutation status remain unknown, limiting the development of therapeutic antibodies targeting the ras gene. Thus, the present study was performed to investigate the subtypes of $\mathrm{p} 21 \mathrm{Ras}$ proteins and mutation status in CRC by immunohistochemistry and direct sequence analysis to explore whether or not wild-type p21Ras could be a target for CRC therapy.

\section{Materials and methods}

Samples. All samples were collected from archives at the Kunming General Hospital between April 2009 and May 2015. This study was approved by the Ethics Committee of Kunming General Hospital. Written informed consent was provided by all patients. A total of 378 samples were used, including 45 cases of normal colorectal tissues (with a 5-cm distance from the tumor margin), 73 cases of colorectal inflammatory polyps, 48 cases of colorectal low-grade intraepithelial neoplasia, 83 cases of colorectal high-grade intraepithelial neoplasia and 129 cases of colorectal cancers. All of the samples were formalin-fixed and paraffin embedded (FFPE).

Among the 129 CRC patients, 85 were males and 44 were females with an average age of 58.06 years (range 30-93 years). Microscopically, 48 were poorly differentiated, 58 were moderately differentiated, and 13 were well differentiated. Seventy-eight patients presented with regional lymph node metastasis. All of the patients receive no radiation therapy or neoadjuvant chemotherapy prior to surgery.

Antibodies. Monoclonal antibody KGH-R1 which is able to react with all three subtypes of p21Ras, H-p21Ras, N-p21Ras and K-p21Ras, was prepared in our laboratory (26). Monoclonal antibody 60309-1-Ig to K-p21Ras was purchased from ProteinTech Group (Chicago, IL, USA), and monoclonal antibody sc-31 to N-p21Ras and monoclonal antibody sc-29 to H-p21Ras were purchased from Santa Cruz Biotechnology, Inc. (Santa Cruz, CA, USA).

Tissue microarray (TMA) construction. FFPE colorectal tissue samples were selected for TMA construction (Boyikang, Beijing, China). Briefly, the areas containing cancer tissues were annotated on hematoxylin and eosin (H\&E) slides and identified by two pathologists. Four-millimeter cores were removed from the selected area (region of interest) with a needle punch. These 4-mm donor cores were subsequently embedded in previously arranged recipient paraffin blocks through a precisely spaced 36-hole array pattern. Core positions in the recipient paraffin block were noted on a TMA map. After paraffin was intenerated and cooling, the recipient blocks were cut using a microtome and used for immunohistochemistry.

Immunohistochemistry. Sections $(4-\mu \mathrm{m})$ from the TMA containing CRC and normal tissues were collected on glass slides coated with adhesive polylysine. The sections were incubated in an oven at $60^{\circ} \mathrm{C}$ for $3 \mathrm{~h}$, then deparaffinized in xylene, hydrated in descending concentrations of ethanol (2 x 100\% for $3 \mathrm{~min}, 95 \%$ for $3 \mathrm{~min}$ and $85 \%$ for $3 \mathrm{~min}$ ) and washed in double-distilled water three times. Subsequently, the slides were subjected to specific epitope unmasking by an autoclave (1600 W, $2 \mathrm{~min})$ in citrate acid buffer (0.01 M pH 6.0), and then exposed to $3 \% \mathrm{H}_{2} \mathrm{O}_{2}$ to block endogenous peroxidase reactivity for $10 \mathrm{~min}$, followed by washing in distilled water. To avoid unspecific staining, $10 \%$ BSA was used to block the sections for $40 \mathrm{~min}$ at $37^{\circ} \mathrm{C}$. Then the sections were incubated in the p21Ras monoclonal antibody at $4^{\circ} \mathrm{C}$ overnight. Controls were obtained by incubating serial sections with the blocking solution but incubated in phosphate-buffered solutions (PBS, pH 7.2) instead of the primary antibodies, and then washed in $0.01 \mathrm{~mol} / \mathrm{l} \mathrm{PBS}$. The sections were then sequentially exposed to horseradish peioxidase secondary antibody (ZSGB-BIO, Beijing, China) for $30 \mathrm{~min}$, and washed with PBS three times. To visualize the sections, diaminobenzidine as a chromogen was applied for 5-7 min and hematoxylin counterstain for $1 \mathrm{~min}$. Finally, all slides were dehydrated and mounted.

The expression of p21Ras was evaluated by the percentage of positive cells and histological score (Hscore) (27). Briefly, at least 300 cells were counted in every component on every slide. The staining patterns were graded as membranous or cytoplasmic. Protein immunoreactivity was scored according to the intensity of staining, which was graded on an arbitrary scale ranging from 0 to 3: 0 , negative (no stained cells); 1 , low (primrose yellow cells); 2, medium (yellow cells); and 3, high expression (tawny cells). A mean percentage of positive tumor cells was determined in at least 3 areas at $x 40$ magnifications and ranged from 0 to $100 \%$.

DNA extraction. Tumor areas in the FFPE tissue blocks were circled by two experienced pathologists. FFPE serial sections $(10-\mu \mathrm{m})$ were used for DNA extraction by means of the QIAamp DNA FFPE tissue kit according to the QIAamp DNA FFPE tissue handbook. The purity of the extracted DNA was tested using an ultraviolet spectrophotometer.

PCR amplification reaction. Primer 5.0 and oligo softwares were used to design primers for $K$-ras, $N$-ras and $H$-ras amplication. Primer sequences were as follows $K$-ras exon 2 sense, 5'-TTA TTATAAGGCCTGCTG-3' and antisense, 5'-TGTATCAAAGA ATGGTCC-3'; K-ras exon 3 sense, 5'-GTGTTTCTCCCTTC TCAG-3' and antisense, 5'-GGCATTAGCAAAGACTCA-3'; $K$-ras exon 4 sense, 5'-TGTTACTAATGACTGTGCTA-3' and antisense, 5'-TAACAGTTATGATTTTGC-3'; $K$-ras exon 5 sense, 5'-ACATGGCTTTCCCAGTAA-3' and antisense, 5'-GTTGCC ACCTTGTTACCT-3'; $N$-ras exon 2 sense, 5'-AATTAACCCTG ATTACTGG-3' and antisense, 5'-TAAAGATGATCCGAC AAG-3'; $N$-ras exon 3 sense, 5'-TAACCTTGGCAATAGCAT-3' and antisense, 5'-TAACCTCATTTCCCCATA-3'; $N$-ras exon 4 sense, 5'-CATGAGCCACTGTACCCA-3' and antisense, 5'-TTG CACAAATGCTGAAAG-3'; $N$-ras exon 5 sense, 5'-GAGATA CAAATGCAAGAG-3' and antisense, 5'-AAACACCAGCACT CCT-3'; H-ras exon 2 sense, 5'-AGACCCTGTAGGAGGACCC-3' and antisense, 5'-CTGCTGGCACCTGGAC-3'; H-ras exon 3 sense, 5'-CACGGAAGGTCCTGAGGGG-3' and antisense, 5'-GCCTGGCCCCACCTGTG-3'; H-ras exon 4 sense, 5'-CTC TCGCTTTCCACCTCT-3' and antisense, 5'-AGCTGTGGGG 
Table I. p21Ras expression in benign lesions and malignant tumors of colorectal cancer.

\begin{tabular}{|c|c|c|c|c|c|c|}
\hline Tissue & $\mathrm{n}$ & Positive & $\begin{array}{c}\text { Percentage of } \\
\text { positive tissues }(\%)\end{array}$ & Intensity & $\begin{array}{c}\text { Percentage of } \\
\text { positive cells }(\%)\end{array}$ & Hscore \\
\hline Normal epithelium & 45 & 0 & 0 & 0.0123 & $1.23 \pm 2.98$ & $1.23 \pm 2.98$ \\
\hline Inflammatory polyps & 73 & 7 & 9.59 & 0.0741 & $7.06 \pm 15.64$ & $7.41 \pm 16.74$ \\
\hline Low-grade intraepithelial neoplasia & 48 & 31 & 64.58 & 0.6654 & $53.33 \pm 42.36$ & $66.54 \pm 59.91$ \\
\hline High-grade intraepithelial neoplasia & 83 & 50 & 60.24 & 0.942 & $57.28 \pm 48.73$ & $94.2 \pm 87.46$ \\
\hline Colorectal carcinoma & 94 & 61 & 64.89 & 1.161 & $63.11 \pm 47.11$ & $116.14 \pm 103.30$ \\
\hline
\end{tabular}
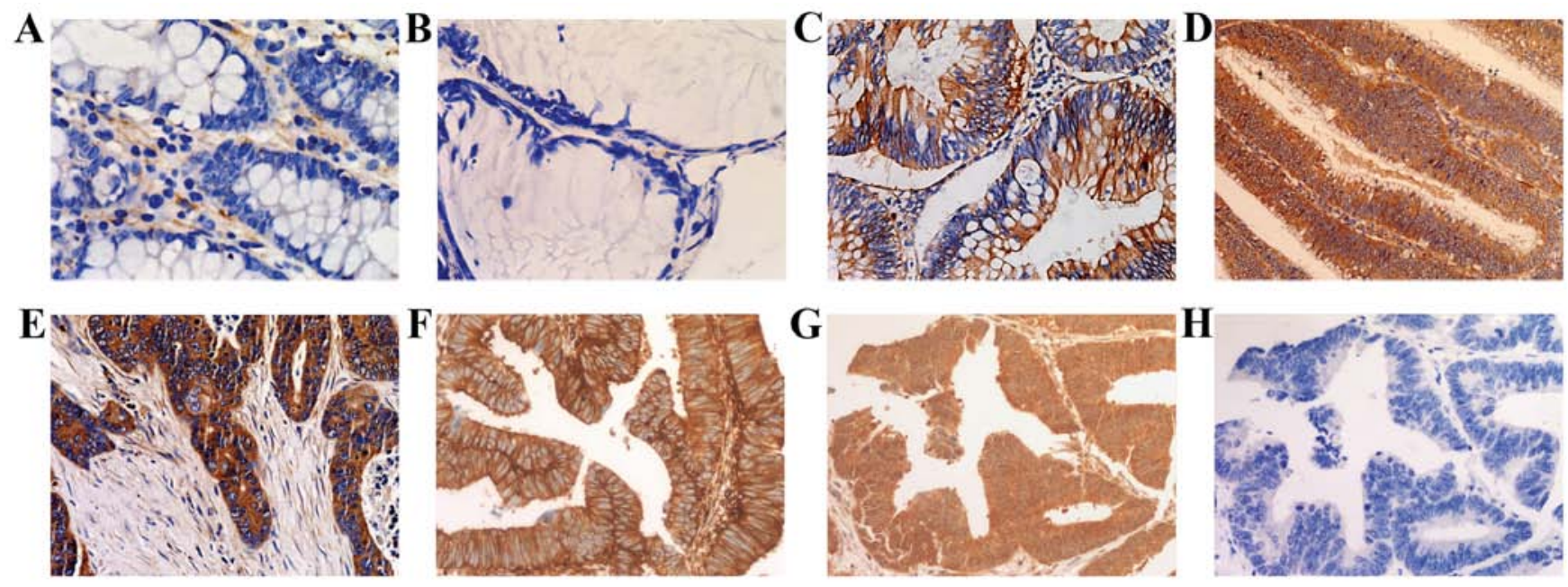

Figure 1. Expression of total p21Ras and p21Ras subtypes was detected by immunohistochemistry. (A-E) Total p21Ras expression detected by Mab KGHR-1. (A) Negative staining in NE; (B) negative staining in IP; (C) strong staining in LIN; (D) strong staining in HIN; (E) strong staining in CRC. (F-H) Expression of p21Ras subtypes in CRC. (F) Strong staining of K-p21Ras; (G) strong staining of N-p21Ras; (H) no staining of H-p21Ras. NE, normal epithelium; IP, inflammatory polyps; LIN, low-grade intraepithelial neoplasia; HIN, high-grade intraepithelial neoplasia; CRC, colorectal cancer.

TGGAGA-3'; H-ras exon 5 sense, 5'-GGCAGGCGGCCAC AGG-3' and antisense, 5'-ATCCGGTGGGCGTGGC-3'. Human $K$-ras, $N$-ras and $H$-ras gene sequences were obtained from GeneBank AF493917, AF493919 and AF493916, respectively. Exon 1 is an untranslated region (UTR). The amplification was performed in a final volume of $25 \mu \mathrm{l}$ containing $2.5 \mu \mathrm{l} 10 \mathrm{X}$ PCR buffer, $2 \mu \mathrm{l}$ dNTP mixture, $1.0 \mu \mathrm{l} \mathrm{Taq}$ enzyme, $1.0 \mu \mathrm{l}$ forward primer $(10 \mu \mathrm{mol} / \mathrm{l}), 1.0 \mu \mathrm{l}$ reverse primer $(10 \mu \mathrm{mol} / \mathrm{l})$, and at least 800 ng DNA. PCR reaction conditions were as follows: initial denaturation at $95^{\circ} \mathrm{C}$ for $4 \mathrm{~min}, 30$ cycles at $95^{\circ} \mathrm{C}$ for $30 \mathrm{sec}$, suited annealing temperature for $30 \mathrm{sec}$, amplification at $72^{\circ} \mathrm{C}$ for $30 \mathrm{sec}$; and a final extension at $72^{\circ} \mathrm{C}$ for $10 \mathrm{~min}$. The PCR amplification products were separated by $1 \%$ agarose gel electrophoresis (AGE) for $30 \mathrm{~min}$ and imaged using the Syngene imaging system (Synoptics Ltd., Cambridge UK).

DNA sequence analysis. Twenty microliters of PCR products were sent to the Beijing Genomics Institute (BGI) for sequencing. The sequencing was conducted in both directions (forward and reverse), and then analyzed by Align X (Invitrogen, Carlsbad, CA, USA) and Chromas (Technelysium Pty Ltd., Queensland, Australia) softwares.

Statistical analysis. The statistical analysis was performed using the SPSS software package, standard version 22.0 (SPSS
Inc., Chicago, IL, USA). Data are expressed as mean \pm SD. Statistical significance was determined by the Student's t-test. A value of $\mathrm{P}<0.05$ was considered to indicate a statistically significant difference.

\section{Results}

Expression of p21Ras. p21Ras expression was detected in none of the normal colorectal epithelium (0/45), in $9.59 \%$ of the inflammatory polyps (7/73), in $64.58 \%$ of the lowgrade intraepithelial neoplasia samples (31/48), in $60.24 \%$ of the high-grade intraepithelial neoplasia samples $(50 / 83)$ and $64.89 \%$ of invasive colorectal carcinoma samples (61/94) (Fig. 1 and Table I). The expression products were localized in the cytoplasm and cell membrane.

We used the percentage of positive cells and Hscore to evaluate the expression level of p21Ras. In normal colorectal epithelium, inflammatory polyps, low-grade intraepithelial neoplasia, high-grade intraepithelial neoplasia and invasive colorectal carcinoma samples, the mean percentages of positive cells were $1.23 \pm 2.98,7.06 \pm 15.64,53.33 \pm 42.36,57.28 \pm 48.73$ and $63.11 \pm 47.11 \%$, and the mean Hscores were $1.23 \pm 2.98$, $7.41 \pm 16.74,66.54 \pm 59.91,94.20 \pm 87.46$ and $116.14 \pm 103.30$, respectively (Fig. 2 and Table I), which indicated a gradual increase from normal colorectal epithelium to CRC. 
A

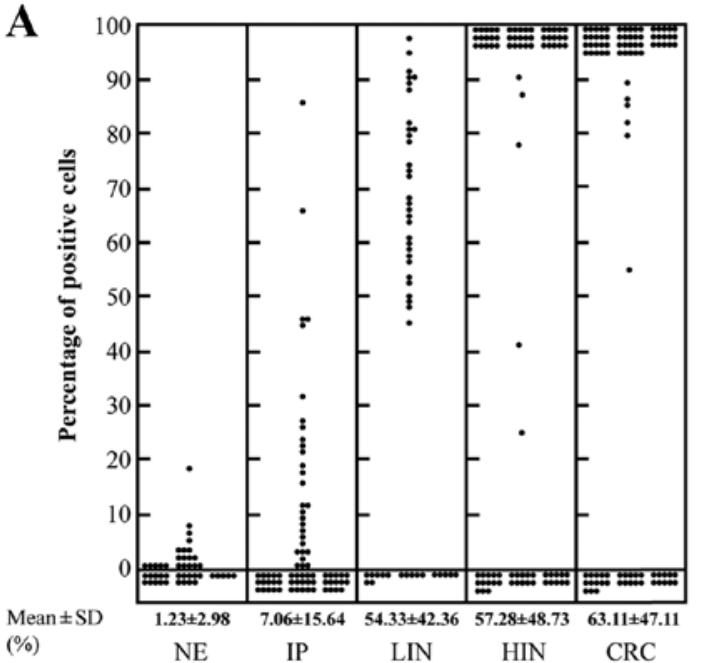

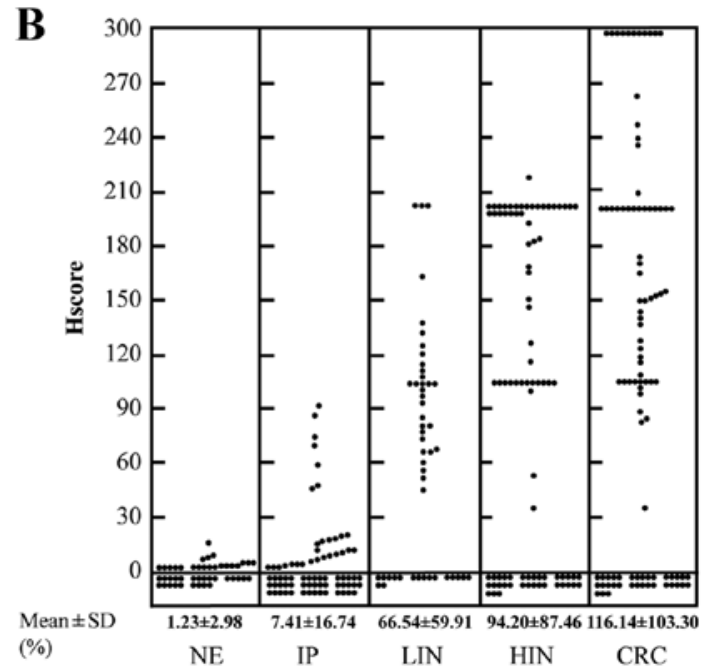

Figure 2. The percentage of positive cells and Hscore of p21Ras expression in the different colorectal lesions. (A) The percentage of positive cells of p21Ras distributed in normal, hyperplastic and malignant lesions of colorectal tissue. (B) The Hscore of p21Ras expression for each sample in hyperplastic and malignant lesions of colorectal tissue. Hscore, histological score. NE, normal epithelium; IP, inflammatory polyps; LIN, low-grade intraepithelial neoplasia; HIN, high-grade intraepithelial neoplasia; CRC, colorectal cancer.

Table II. Correlation between p21Ras expression and the clinicopathologic features of the invasive colorectal adenocarcinoma patients.

\begin{tabular}{|c|c|c|c|c|c|}
\hline $\begin{array}{l}\text { Clinicopathologic } \\
\text { features }\end{array}$ & Cases $(\mathrm{N}=94)$ & Hscore & P-value & $\begin{array}{c}\text { Percentage of } \\
\text { positive cells }(\%)\end{array}$ & P-value \\
\hline Gender & & & $>0.05$ & & $>0.05$ \\
\hline Male & 64 & $114.29 \pm 103.76$ & & $63.33 \pm 46.78$ & \\
\hline Female & 30 & $120.10 \pm 103.97$ & & $62.63 \pm 48.62$ & \\
\hline Age (years) & & & $>0.05$ & & $>0.05$ \\
\hline$\leq 50$ & 28 & $105.07 \pm 104.43$ & & $55.95 \pm 49.55$ & \\
\hline$<50$ & 66 & $120.84 \pm 103.26$ & & $66.14 \pm 46.09$ & \\
\hline Histologic type & & & $<0.05$ & & $<0.05$ \\
\hline Non-mucinous adenocarcinoma & 84 & $121.43 \pm 101.70$ & & $66.40 \pm 46.20$ & \\
\hline Mucinous adenocarcinoma & 10 & $35.4 \pm 66.99$ & & $25.40 \pm 42.77$ & \\
\hline Differentiation & & & $<0.01$ & & $<0.01$ \\
\hline Well & 13 & $40.92 \pm 73.16$ & & $28.77 \pm 45.08$ & \\
\hline Moderate & 34 & $102.78 \pm 90.99$ & & $63.75 \pm 47.95$ & \\
\hline Poor & 47 & $182.08 \pm 91.68$ & & $87.47 \pm 31.42$ & \\
\hline Invasive depth & & & $>0.05$ & & $>0.05$ \\
\hline Superficial muscle & 7 & $83.71 \pm 83.61$ & & $57.14 \pm 53.45$ & \\
\hline Deep muscle & 17 & $103.65 \pm 108.56$ & & $57.59 \pm 49.91$ & \\
\hline Full thickness & 70 & $122.42 \pm 104.20$ & & $65.04 \pm 46.37$ & \\
\hline Tumor size $(\mathrm{cm})$ & & & $>0.05$ & & $>0.05$ \\
\hline$<2$ & 12 & $72.17 \pm 93.12$ & & $45.96 \pm 48.44$ & \\
\hline $2-5$ & 59 & $123.94 \pm 101.51$ & & $67.81 \pm 45.85$ & \\
\hline$>5$ & 22 & $119.09 \pm 111.27$ & & $60.00 \pm 49.36$ & \\
\hline Lymph node metastasis & & & $<0.05$ & & $<0.05$ \\
\hline- & 63 & $131.21 \pm 104.57$ & & $68.97 \pm 45.88$ & \\
\hline+ & 31 & $85.52 \pm 95.06$ & & $51.19 \pm 48.12$ & \\
\hline
\end{tabular}

Correlation between p21Ras expression and clinicopathologic variables. A total of $94 \mathrm{CRC}$ cases were adopted here.
There was a statistical correlation between histologic type and Hscores, and also lymph node metastasis and Hscores 
Table III. p21Ras expression and ras mutations in CRC.

\begin{tabular}{|c|c|c|c|c|c|c|c|c|}
\hline \multirow[b]{2}{*}{ Patients } & \multicolumn{3}{|c|}{$K$-ras } & \multicolumn{2}{|c|}{$N$-ras } & \multicolumn{3}{|c|}{ H-ras } \\
\hline & Expression & Exon & Mutation & Expression & Mutation & Expression & Exon & Mutation \\
\hline 201503220 & + & Exon 4 & c. $436 \mathrm{G}>\mathrm{A} \rightarrow$ p.A146T & - & - & - & Exon 2 & c. $81 \mathrm{~T}>\mathrm{C}$ \\
\hline 201503213 & + & - & - & - & - & - & Exon 2 & c. $81 \mathrm{~T}>\mathrm{C}$ \\
\hline 201503102 & + & - & - & - & - & - & - & - \\
\hline 201502928 & + & Exon 4 & c. $436 \mathrm{G}>\mathrm{A} \rightarrow \mathrm{p} . \mathrm{A} 146 \mathrm{~T}$ & + & - & - & - & - \\
\hline 201502903 & + & - & - & + & - & - & Exon 2 & c. $81 \mathrm{~T}>\mathrm{C}$ \\
\hline 201502056 & + & Exon 2 & c. $35 \mathrm{G}>\mathrm{A} \rightarrow \mathrm{p} . \mathrm{G} 12 \mathrm{D}$ & + & - & - & - & - \\
\hline 201501338 & + & - & - & + & - & - & Exon 2 & c. $81 \mathrm{~T}>\mathrm{C}$ \\
\hline 201501304 & + & - & - & + & - & - & - & - \\
\hline 201500934 & + & - & - & + & - & - & Exon 2 & c. $81 \mathrm{~T}>\mathrm{C}$ \\
\hline 201500667 & + & - & - & + & - & - & - & - \\
\hline 201412412 & + & Exon 2 & c. $38 \mathrm{G}>\mathrm{A} \rightarrow$ p.G13D & + & - & - & - & - \\
\hline 201410010 & + & - & - & + & - & - & - & - \\
\hline 201409737 & + & Exon 2 & c. $38 \mathrm{G}>\mathrm{A} \rightarrow \mathrm{p} . \mathrm{G} 13 \mathrm{D}$ & + & - & - & - & - \\
\hline 201408315 & + & Exon 2 & c. $35 \mathrm{G}>\mathrm{C} \rightarrow \mathrm{p} . \mathrm{G} 12 \mathrm{~A}$ & + & - & - & Exon 2 & c. $81 \mathrm{~T}>\mathrm{C}$ \\
\hline 201407762 & + & - & - & + & - & - & - & - \\
\hline 201406231 & + & Exon 4 & c. $436 \mathrm{G}>\mathrm{A} \rightarrow \mathrm{p} . \mathrm{A} 146 \mathrm{~T}$ & & & & & \\
\hline & & Exon 5 & c.526 $>\mathrm{T} \rightarrow$ p.E176Stop & - & - & - & - & - \\
\hline 201405694 & + & - & - & + & - & - & Exon 2 & c. $81 \mathrm{~T}>\mathrm{C}$ \\
\hline 201405647 & + & Exon 2 & c. $.35 \mathrm{G}>\mathrm{A} \rightarrow \mathrm{p} . \mathrm{G} 12 \mathrm{D}$ & + & - & - & Exon 2 & c. $81 \mathrm{~T}>\mathrm{C}$ \\
\hline 201503581 & + & - & - & + & - & - & - & - \\
\hline 201503452 & + & - & - & - & - & - & - & - \\
\hline 201502977 & + & Exon 5 & c. $.467 \mathrm{~T}>\mathrm{C} \rightarrow \mathrm{p} . \mathrm{F} 156 \mathrm{~S}$ & + & - & - & - & - \\
\hline 201502204 & + & - & - & + & - & - & - & - \\
\hline 201501593 & + & Exon 2 & c. $35 \mathrm{G}>\mathrm{T} \rightarrow \mathrm{p} . \mathrm{G} 12 \mathrm{~V}$ & + & - & - & Exon 2 & c. $81 \mathrm{~T}>\mathrm{C}$ \\
\hline 201501337 & + & - & - & + & - & - & - & - \\
\hline 201501079 & + & - & - & + & - & - & - & - \\
\hline 201407828 & + & Exon 2 & c. $38 \mathrm{G}>\mathrm{A} \rightarrow \mathrm{p} . \mathrm{G} 13 \mathrm{D}$ & + & - & - & - & - \\
\hline 201407425 & + & - & - & + & - & - & Exon 2 & c. $81 \mathrm{~T}>\mathrm{C}$ \\
\hline 201407236 & + & Exon 2 & c. $35 \mathrm{G}>\mathrm{A} \rightarrow$ p.G12D & + & - & - & - & - \\
\hline 201405983 & + & Exon 2 & c. $38 \mathrm{G}>\mathrm{A} \rightarrow$ p.G13D & + & - & - & Exon 2 & c. $81 \mathrm{~T}>\mathrm{C}$ \\
\hline 201405149 & + & - & - & + & - & - & - & - \\
\hline 201404719 & + & - & - & + & - & - & - & - \\
\hline 201404718 & + & Exon 2 & c. $38 \mathrm{G}>\mathrm{A} \rightarrow$ p.G13D & + & - & - & Exon 2 & c. $81 \mathrm{~T}>\mathrm{C}$ \\
\hline 201404238 & + & - & - & + & - & - & - & - \\
\hline 201401791 & + & - & - & + & - & - & - & - \\
\hline 201401610 & + & - & - & + & - & - & Exon 2 & c. $81 \mathrm{~T}>\mathrm{C}$ \\
\hline
\end{tabular}

$(\mathrm{P}<0.05)$. However, no correlation was observed between Hscore and the other patient clinicopathologic parameters $(\mathrm{P}>0.05)$, which suggests that the expression of $\mathrm{p} 21 \mathrm{Ras}$ and indices such as gender, age, invasive depth are independent events. Furthermore, the same results were found between the percentage of positive cells and the clinicopathologic variables (Table II).

Expression of p21Ras subtypes in CRC. Three Mabs, each of which is able to recognize one of the p21Ras subtypes were used to detect the expression of the three p21Ras subtypes by immunohistochemistry (Fig. 1). It was demonstrated that K-p21Ras was expressed in all 35 CRC, N-p21Ras was expressed in 30/35 of CRC samples, and H-p21Ras was not expressed in all of the CRCs tested (Table III). Notably, overexpression of both K-p21Ras and N-p21Ras were detected in 30 cases (Table III). Analysis of the immunohistochemical staining of K-p21Ras, N-p21Ras and H-p21Ras was also evaluated according to the percentage of positive cells and Hscore, which were $92.08 \pm 10.98,77.00 \pm 33.21,0 \%$ and $180.08 \pm 50.81$, $154.04 \pm 92.26,0$, respectively.

Ras mutation status in CRC. All 12 exons of $K$-ras, $N$-ras and $H$-ras in 35 of the CRC cases were amplified successfully 


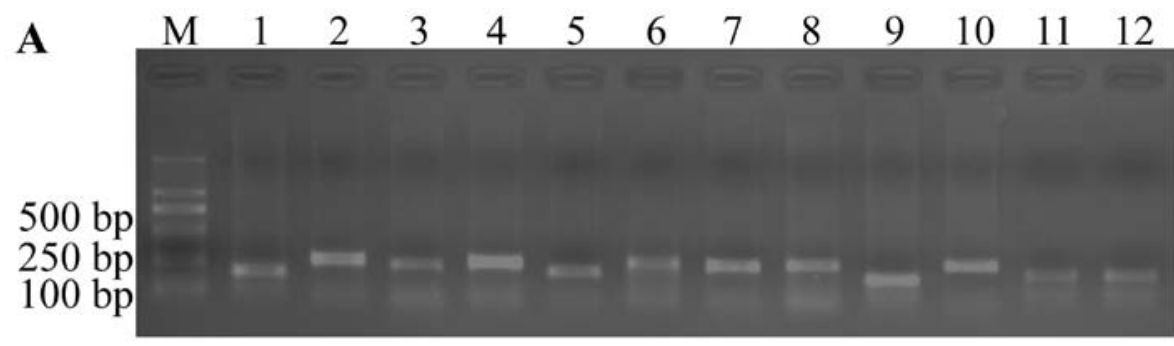

B
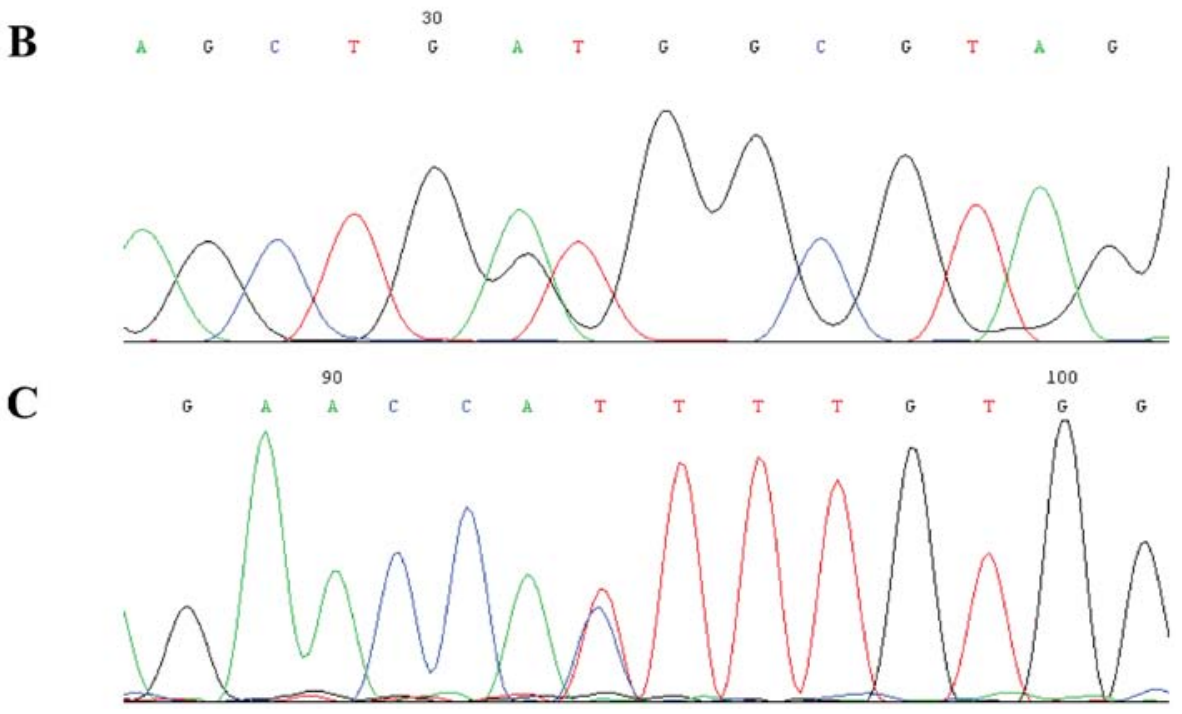

Figure 3. Mutation status of ras was detected by direct sequencing. (A) Representative $1 \%$ agarose gel revealing 12 exon amplicons in CRC. $K$-ras exon $2-5$ (lane 1-4), $N$-ras exon 2-5 (lane 5-8), $H$-ras exon 2-5 (lane 9-12). (B) K-ras mutation in CRC (c.35G>A). (C) H-ras mutation in CRC (c.81C $>$ T). CRC, colorectal cancer.

by designed primers. Each PCR product was confirmed by agarose gel electrophoresis with expected sizes of 185,274 , 255, 263, 217, 339, 255, 286, 187, 276, 207 and 215 bp, respectively (Fig. 3).

Among the 35 cases of CRC with K-p21Ras overexpression, $K$-ras mutations were detected in $40 \%$ of the cases (14/35), however, $K$-ras mutations were not detected in the other $60 \%$ of CRC cases which indicated that the overexpression of p21Ras in these $60 \% \mathrm{CRC}$ were wild-type. $K$-ras mutation was present in codon 12 (5 cases), 13 (5 cases), 146 (3 cases), 156 ( 1 case) and 176 ( 1 case). The most frequent K-ras mutation was transition of base G/A $(5 / 14,35.7 \%)$ in codon 13 , which resulted in the substitution of glycine with aspartate. $\mathrm{N}$-ras mutations were not found in all 30 of the N-p21Ras-overexpressing CRC cases (Table III). In CRC without N-p21Ras expression no $\mathrm{N}$-ras mutation was detected, and in CRC without H-p21Ras expression only a $H$-ras nonsense mutation at codon 27 was found (Fig. 3).

\section{Discussion}

Amplification of oncogenes and protein overexpression have been identified in various solid tumors. Overexpression of the human epidermal growth factor receptor 2 (HER2) gene occurs in $15-25 \%$ of human breast cancers (28). EGFR is overexpressed in $40-60 \%$ of non-small cell lung cancer cases (23). Overexpression is considered to be the main activation mechanisms of oncogenes, and oncogene proteins could be potential targets for cancer therapy. Trastuzumab (29), pertuzumab (30) and lapatinib (31) targeting HER2 protein have been approved as standard care for inhibiting HER2 activity in the treatment of HER2-positive breast cancer. Cetuximab $(3,32)$, panitumumab $(4,33)$ and nimotuzomab (34) targeting EGFR protein have been used to treat human cancers with EGFR overexpression, such as CRC and non-small cell lung cancer.

Ras gene protein p21Ras was found to be overexpressed in most human tumors, including CRC (35), bladder cancer (36), breast cancer $(37,38)$, stomach adenocarcinomas (39), thyroid cancer (40) and laryngeal cancer (41). However, no targeted drugs that target against p21Ras directly have been exploited. Recently, we prepared a novel anti-p21Ras Mab, KGH-R1, which can recognize and react with three type of p21Ras, including H-p21Ras, $\mathrm{N}$-p21Ras and K-p21Ras, and the single chain antibody derived from this Mab could regress p21Ras-overexpressing tumors in vitro and in vivo $(26,42)$. In this study, the Mab was employed to examine p21Ras expression in normal colorectal epithelium, inflammatory polyps, low-grade intraepithelial neoplasia, highgrade intraepithelial neoplasia and invasive CRC. The results showed that there was almost no p21Ras expression in normal colorectal mucosa, but high level expression of p21Ras in CRC and colorectal intraepithelial neoplasia. Together with the reported data $(15,43-46)$, we confirmed that p21Ras overexpression is an important event in colorectal carcinogenesis and plays a major role in the development of CRC.

Subsequently, we evaluated expression of p21Ras subtypes by immunohistochemistry using anti-K-ras, anti-N-ras or antiH-ras Mab, and found that K-p21Ras was expressed in all of 
the tested CRC tissues, which was significantly higher than the results of Elsabah and Adel (42.3\%) (47). The different frequency of Ras expression probably resulted from region variations, and the difference in sample sources $(48,49)$. Additionally, we found that N-p21Ras was expressed in $85.7 \%$ of the CRC cases, but H-p21Ras was not expressed in any tested CRC case. Our data indicated that K-p21Ras and $\mathrm{N}$-p21Ras are deeply involved in CRC development.

Furthermore, DNA sequencing was used to reveal the mutation status of the overexpressed p21Ras, and found that $60 \%$ of K-p21Ras-overexpressing CRC samples did not harbor $K$-ras mutation. $N$-ras mutation was not found in any of the N-p21Ras-overexpressing CRCs. Thus, overexpression of the wild-type p21Ras may be another important mechanism in CRC development, and the therapeutic antibodies targeting wild-type p21Ras may have better prospect for the therapy of CRC. To date, few studies have reported the overexpression of wild-type p21Ras in cancers. To the best of our knowledge, this is the first time to reveal wild-type p21Ras expression in CRC. The mechanism involved in the induction of tumorigenesis by the overexpression of wild-type p21Ras remains unclear. Zheng et al reported that overexpression of the wild-type N-p21Ras induces IL- 8 by binding and activating the cytoplasmic pool of JAK2. IL-8 then acts on tumor cells and promotes the progression of cancer (50). In addition, we speculated that overexpression of the wild-type p21Ras leads to the excessive GTP-bound active form that cannot be completely hydrolyzed, and finally stimulates persistent cell proliferation and tumorigenesis. However, on the other hand, Spandidos and Wilkie reported that after rat 208F cells (a derivative of Rat-1 cells) were transfected with T24 mutant $H$-ras (51) or the mutant $N$-ras (52), the expression level of normal $H$-rasl gene was elevated, leading to suppression of the transformed and tumorigenic phenotypes induced by mutant ras genes. Thus, wild-type H-p21Ras plays a complex role in the development of cancers, and further studies are needed to clarify the mechanisms of wild-type p21Ras overexpression in cancer development.

In conclusion, we detected the expression level of p21Ras in benign and malignant CRC, as well as the p21Ras subtypes and mutation status of the ras gene in CRC. We conclude that the overexpression of wild-type p21Ras, especially wild-type K-p21Ras and N-p21Ras play a prominent role in the development of CRC. This also implies that wild-type p21Ras is a promising target for CRC therapy and it is feasible to develop the antibody drugs against wild-type p21Ras.

\section{Acknowledgements}

The present study was supported by grants from the National Natural Science Foundation of China (no. 81460464) and the Applied Foundation Key Project of Yunnan Province (no. 2013FA059).

\section{References}

1. Siegel RL, Miller KD and Jemal A: Cancer statistics, 2016. CA Cancer J Clin 66: 7-30, 2016.

2. Cunningham D, Atkin W, Lenz HJ, Lynch HT, Minsky B, Nordlinger B and Starling N: Colorectal cancer. Lancet 375: $1030-1047,2010$
3. Jonker DJ, O'Callaghan CJ, Karapetis CS, Zalcberg JR, Tu D, Au HJ, Berry SR, Krahn M, Price T, Simes RJ, et al: Cetuximab for the treatment of colorectal cancer. N Engl J Med 357: 2040-2048, 2007.

4. Sartore-Bianchi A, Moroni M, Veronese S, Carnaghi C, Bajetta E, Luppi G, Sobrero A, Barone C, Cascinu S, Colucci G, et al: Epidermal growth factor receptor gene copy number and clinical outcome of metastatic colorectal cancer treated with panitumumab. J Clin Oncol 25: 3238-3245, 2007.

5. Del Vecchio Blanco G, Paoluzi OA, Sileri P, Rossi P, Sica G and Pallone F: Familial colorectal cancer screening: When and what to do? World J Gastroenterol 21: 7944-7953, 2015.

6. Jonker DJ, Karapetis CS, Harbison C, O'Callaghan CJ, Tu D, Simes RJ, Malone DP, Langer C, Tebbutt N, Price TJ, et al: Epiregulin gene expression as a biomarker of benefit from cetuximab in the treatment of advanced colorectal cancer. Br J Cancer 110: 648-655, 2014.

7. Adjei AA: Blocking oncogenic Ras signaling for cancer therapy. J Natl Cancer Inst 93: 1062-1074, 2001.

8. Bos JL, Fearon ER, Hamilton SR, Verlaan-de Vries M, van Boom JH, van der Eb AJ and Vogelstein B: Prevalence of ras gene mutations in human colorectal cancers. Nature 327: 293-297, 1987.

9. Ohnishi T, Tomita N, Monden T, Ohue M, Yana I, Takami K, Yamamoto H, Yagyu T, Kikkawa N, Shimano T, et al: A detailed analysis of the role of K-ras gene mutation in the progression of colorectal adenoma. Br J Cancer 75: 341-347, 1997.

10. Puerta-García E, Cañadas-Garre $M$ and CallejaHernández MA: Molecular biomarkers in colorectal carcinoma. Pharmacogenomics 16: 1189-1222, 2015.

11. Liu X, Jakubowski M and Hunt JL: KRAS gene mutation in colorectal cancer is correlated with increased proliferation and spontaneous apoptosis. Am J Clin Pathol 135: 245-252, 2011.

12. Andreyev HJ, Norman AR, Cunningham D, Oates J, Dix BR, Iacopetta BJ, Young J, Walsh T, Ward R, Hawkins $\mathrm{N}$, et al: Kirsten ras mutations in patients with colorectal cancer: The 'RASCAL II' study. Br J Cancer 85: 692-696, 2001.

13. Chang YS, Chang SJ, Yeh KT, Lin TH and Chang JG: RAS, BRAF, and TP53 gene mutations in Taiwanese colorectal cancer patients. Onkologie 36: 719-724, 2013.

14. Palmirotta R, Savonarola A, Ludovici G, De Marchis ML, Covello R, Ettorre GM, Ialongo C and Guadagni F: Concurrent mutation in exons 1 and 2 of the K-ras oncogene in colorectal cancer. Folia Histochem Cytobiol 49: 729-733, 2011.

15. Salhab N, Jones DJ, Bos JL, Kinsella A and Schofield PF: Detection of ras gene alterations and ras proteins in colorectal cancer. Dis Colon Rectum 32: 659-664, 1989.

16. Thomas RJ, Liu YS, St Clair F, Norris PM, Valentine R and Phillips WA: Frequency and clinico-pathological associations of ras mutations in colorectal cancer in the Victorian population. Aust NZ J Surg 67: 233-238, 1997.

17. Yaeger R, Cowell E, Chou JF, Gewirtz AN, Borsu L, Vakiani E, Solit DB, Rosen N, Capanu M, Ladanyi M, et al: RAS mutations affect pattern of metastatic spread and increase propensity for brain metastasis in colorectal cancer. Cancer 121: 1195-1203, 2015.

18. Kiaris H and Spandidos D: Mutations of ras genes in human tumors (Review). Int J Oncol 7: 413-421, 1995.

19. Irahara N, Baba Y, Nosho K, Shima K, Yan L, Dias-Santagata D, Iafrate AJ, Fuchs CS, Haigis KM and Ogino S: NRAS mutations are rare in colorectal cancer. Diagn Mol Pathol 19: 157-163, 2010.

20. Glarakis IS, Savva S and Spandidos DA: Activation of the ras genes in malignant and premalignant colorectal tumors. Oncol Rep 5: 1451-1454, 1998.

21. Boidot R, Chevrier S, Julie V, Ladoire S and Ghiringhelli F: HRAS G13D, a new mutation implicated in the resistance to anti-EGFR therapies in colorectal cancer, a case report. Int J Colorectal Dis 31: 1245-1246, 2016.

22. Spandidos DA, Sourvinos G, Tsatsanis C and Zafiropoulos A: Normal ras genes: Their onco-suppressor and pro-apoptotic functions (Review). Int J Oncol 21: 237-241, 2002.

23. Xu N, Fang W, Mu L, Tang Y, Gao L, Ren S, Cao D, Zhou L, Zhang A, Liu D, et al: Overexpression of wild-type EGFR is tumorigenic and denotes a therapeutic target in non-small cell lung cancer. Oncotarget 7: 3884-3896, 2016.

24. Lim SO, Park YM, Kim HS, Quan X, Yoo JE, Park YN, Choi GH and Jung G: Notch1 differentially regulates oncogenesis by wild-type p53 overexpression and p53 mutation in grade III hepatocellular carcinoma. Hepatology 53: 1352-1362, 2011. 
25. McDermott U, Longley DB and Johnston PG: Molecular and biochemical markers in colorectal cancer. Ann Oncol 13 (Suppl 4): 235-245, 2002.

26. Yang JL, Liu DX, Zhen SJ, Zhou YG, Zhang DJ, Yang LY, Chen HB and Feng Q: A novel anti-p21Ras scFv antibody reacting specifically with human tumour cell lines and primary tumour tissues. BMC Cancer 16: 131, 2016.

27. Budwit-Novotny DA, McCarty KS, Cox EB, Soper JT, Mutch DG, Creasman WT, Flowers JL and McCarty KS Jr: Immunohistochemical analyses of estrogen receptor in endometrial adenocarcinoma using a monoclonal antibody. Cancer Res 46: 5419-5425, 1986.

28. Ferretti G, Felici A, Papaldo P, Fabi A and Cognetti F: HER2/neu role in breast cancer: From a prognostic foe to a predictive friend. Curr Opin Obstet Gynecol 19: 56-62, 2007.

29. Baselga J, Manikhas A, Cortés J, Llombart A, Roman L, Semiglazov VF, Byakhov M, Lokanatha D, Forenza S Goldfarb RH, et al: Phase III trial of nonpegylated liposomal doxorubicin in combination with trastuzumab and paclitaxel in HER2-positive metastatic breast cancer. Ann Oncol 25: 592-598, 2014.

30. Swain SM, Kim SB, Cortés J, Ro J, Semiglazov V, Campone M, Ciruelos E, Ferrero JM, Schneeweiss A, Knott A, et al: Pertuzumab, trastuzumab, and docetaxel for HER2-positive metastatic breast cancer (CLEOPATRA study): Overall survival results from a randomised, double-blind, placebo-controlled, phase 3 study. Lancet Oncol 14: 461-471, 2013.

31. Guan Z, Xu B, DeSilvio ML, Shen Z, Arpornwirat W, Tong Z Lorvidhaya V, Jiang Z, Yang J, Makhson A, et al: Randomized trial of lapatinib versus placebo added to paclitaxel in the treatment of human epidermal growth factor receptor 2-overexpressing metastatic breast cancer. J Clin Oncol 31: 1947-1953, 2013.

32. Zhang F, Yu Y, Xing L and Chen M: Cetuximab combined with chemotherapy is beneficial for patients with advanced non-small cell lung cancer after EGFR-tyrosine kinase inhibitors failure. Int J Clin Exp Med 8: 16140-16148, 2015.

33. Socinski MA: Antibodies to the epidermal growth factor receptor in non small cell lung cancer: current status of matuzumab and panitumumab. Clin Cancer Res 13: s4597-4601, 2007.

34. Boland $\mathrm{W}$ and Bebb G: The emerging role of nimotuzumab in the treatment of non-small cell lung cancer. Biologics 4: 289-298, 2010.

35. Hand PH, Thor A, Wunderlich D, Muraro R, Caruso A and Schlom J: Monoclonal antibodies of predefined specificity detect activated ras gene expression in human mammary and colon carcinomas. Proc Natl Acad Sci USA 81: 5227-5231, 1984.

36. Viola MV, Fromowitz F, Oravez S, Deb S and Schlom J: ras oncogene p21 expression is increased in premalignant lesions and high grade bladder carcinoma. J Exp Med 161: 1213-1218, 1985.

37. Ohuchi N, Thor A, Page DL, Hand PH, Halter SA and Schlom J: Expression of the 21,000 molecular weight ras protein in a spectrum of benign and malignant human mammary tissues. Cancer Res 46: 2511-2519, 1986.

38. Ghosh AK, Moore M and Harris M: Immunohistochemical detection of ras oncogene $\mathrm{p} 21$ product in benign and malignant mammary tissue in man. J Clin Pathol 39: 428-434, 1986.
39. Ohuchi N, Hand PH, Merlo G, Fujita J, Mariani-Costantini R, Thor A, Nose M, Callahan R and Schlom J: Enhanced expression of c-Ha-ras p21 in human stomach adenocarcinomas defined by immunoassays using monoclonal antibodies and in situ hybridization. Cancer Res 47: 1413-1420, 1987.

40. Johnson TL, Lloyd RV and Thor A: Expression of ras oncogene p21 antigen in normal and proliferative thyroid tissues. Am J Pathol 127: 60-65, 1987

41. Scambia G, Catozzi L, Benedetti Panici P, Ferrandina G, Almadori G, Paludetti G, Cadoni G, Distefano M, Piffanelli A and Mancuso S: Expression of ras oncogene p21 protein in normal and neoplastic laryngeal tissues: Correlation with histopathological features and epidermal growth factor receptors. Br J Cancer 69: 995-999, 1994.

42. Yang JL, Pan XY, Zhao WX, Hu QC, Ding F, Feng Q, Li GY and Luo Y: The antitumor efficacy of a novel adenovirus-mediated anti-p21Ras single chain fragment variable antibody on human cancers in vitro and in vivo. Int J Oncol 48: 1218-1228, 2016.

43. Sammoud S, Khiari M, Semeh A, Amine L, Ines C, Amira A, Lilia K, Taher K, Sabeh M and Saadia B: Relationship between expression of ras p21 oncoprotein and mutation status of the $\mathrm{K}$-ras gene in sporadic colorectal cancer patients in Tunisia. Appl Immunohistochem Mol Morphol 20: 146-152, 2012.

44. Allen DC, Foster H, Orchin JC and Biggart JD: Immunohistochemical staining of colorectal tissues with monoclonal antibodies to ras oncogene $\mathrm{p} 21$ product and carbohydrate determinant antigen 19-9. J Clin Pathol 40: 157-162, 1987.

45. Sun XF, Wingren S, Carstensen JM, Stål O, Hatschek T, Boeryd B, Nordenskjöld B and Zhang H: ras p21 expression in relation to DNA ploidy, $S$-phase fraction and prognosis in colorectal adenocarcinoma. Eur J Cancer 27: 1646-1649, 1991.

46. Morris VK, Lucas FA, Overman MJ, Eng C, Morelli MP, Jiang ZQ, Luthra R, Meric-Bernstam F, Maru D, Scheet P, et al: Clinicopathologic characteristics and gene expression analyses of non-KRAS 12/13, RAS-mutated metastatic colorectal cancer. Ann Oncol 25: 2008-2014, 2014.

47. Elsabah MT and Adel I: Immunohistochemical assay for detection of $\mathrm{K}$-ras protein expression in metastatic colorectal cancer. J Egypt Natl Canc Inst 25: 51-56, 2013.

48. Hirvikoski P, Auvinen A, Servomaa K, Kiuru A, Rytömaa T, Makkonen K and Kosma VM: K-ras and p53 mutations and overexpressions as prognostic factors in female rectal carcinoma. Anticancer Res 19: 685-691, 1999.

49. Okulczyk B, Kovalchuk O, Piotrowski Z, Myśliwiec P and Chyczewski L: Clinical usefulness of K-RAS mutation detection in colorectal cancer and in surgical margins of the colon. Rocz Akad Med Bialymst 49 (Suppl 1): 52-54, 2004.

50. Zheng ZY, Tian L, Bu W, Fan C, Gao X, Wang H, Liao YH, Li Y, Lewis MT, Edwards D, et al: Wild-type N-Ras, overexpressed in basal-like breast cancer, promotes tumor formation by inducing IL-8 secretion via JAK2 activation. Cell Rep 12: 511-524, 2015.

51. Spandidos A and Wilkie NM: The normal human H-ras1 gene can act as an onco-suppressor. Br J Cancer Suppl 9: 67-71, 1988.

52. Spandidos DA, Frame M and Wilkie NM: Expression of the normal $\mathrm{H}$-ras1 gene can suppress the transformed and tumorigenic phenotypes induced by mutant ras genes. Anticancer Res 10: 1543-1554, 1990. 